\title{
PENGARUH ATRIBUT PRODUK TERHADAP KEPUTUSAN KONSUMEN DALAM PEMBELIAN PRODUK ABON JAMUR TIRAM DI PERUSAHAAN AILANIFOOD KOTA MALANG JAWA TIMUR
}

\section{THE INFLUENCE OF PRODUCT ATTRIBUTES AGAINTS CONSUMER DECISSION IN THE PURCHASE OF FLOSS OYSTER MUSHROOM PRODUCT AILANIFOOD COMPANY IN MALANG EAST JAVA}

\author{
Ahmad Bagus Sudrajad ${ }^{1 *}$, Dwi Retno Andriani ${ }^{2}$ \\ Jurusan Sosial Ekonomi, Fakultas Pertanian, Universitas Brawijaya, Jl. Veteran, Malang 65145, \\ Indonesia
}

Received: 5th August 2015; Revised: 17th November 2015; Accepted: 18th November 2015

\begin{abstract}
ABSTRAK
Abon jamur adalah jenis makanan yang berbentuk serpihan dan kering, terbuat dari jamur tiram yang telah dicampur dengan bumbu dan telah melalui proses penggorengan, abon jamur tersebut diproduksi oleh perusahaan Ailanifood di Kota Malang. Tujuan penelitian ini adalah melihat pengaruh atribut produk terhadap keputusan pembelian abon jamur Ailani di kota Malang. Dengan menganalisis atribut-atribut produk yang berpengaruh signifikan dan dominan. Metode penentuan responden menggunakan accidental sampling. Alat analisis yang digunakan adalah uji Cochran Q dan Regresi Berganda. Pada uji t variabel yang berpengaruh signifikan yaitu kemasan, kualitas, dan harga, sementara variabel paling dominan terhadap Ailani jamur abon keputusan pembelian adalah atribut harga. Dalam penelitian ini menyimpulkan bahwa seluruh atribut produk kecuali merk, seperti (kemasan, kualitas, dan harga) berpengaruh secara signifikan terhadap keputusan pembelian produk abon jamur ailani.
\end{abstract}

Kata kunci: Keputusan; pembelian; atribut produk

\begin{abstract}
The mushrooms mince are a type of food that flaky and dry, made of oyster mushrooms mixed with herbs through frying process, the aim of this research is to identify the influence of product attributes toward purchasing decision of mince. By analyzed the samples significant and dominant products. Method of determination is accidental sampling. Analysis tool used were cochran $Q$ test and Multiple Regression. The result show that attribute of package, quality, and price significantly influence consumer's decisions to buy mushroom mince. In this research concluded that all of produk attribute except brand, such as (package, quality, and price) are significantly influence to costumer purchase decision on mushroom mince ailanifood product.
\end{abstract}

Keywords: Decision; purchasing; product attributes

\section{Pendahuluan}

Dari sektor pertanian merupakan sektor unggulan dalam meningkatkan pertumbuhan perekonomian di Indonesia. Hal ini terlihat dari kontribusinya, terhadap PDB yaitu sebesar 1.311,037 triliun rupiah dari total produk domestik bruto Indonesia tahun 2013

\footnotetext{
${ }^{*}$ Penulis Korespondensi.

E-mail: bagussudrajad92@gmail.com

Telp: +6281336551186
}

(Badan Pusat Statistik, 2014). Berdasar data tersebut, sektor pertanian di Indonesia diharapkan dapat membangun pertumbuhan ekonomi secara baik, tertera dalam hal menyediakan lapangan kerja dan memberikan peluang pengembangan sektor pengolahan hasil pertanian atau agroindustri untuk meningkatkan pendapatan di tingkat wilayah.

Salah satu daerah yang memiliki unit agroindustri cukup banyak yaitu Kota Malang, hal ini dapat dilihat pada tahun 2011 tercatat sebanyak 81 unit agroindustri, dengan rincian 
41 unit agroindustri tembakau dan 40 unit agroindustri olahan makanan dan minuman (BPS Kota Malang, 2012). Fakta tersebut mengindikasikan persaingan dalam dunia usaha semakin ketat, sehingga tiap-tiap perusahaan harus melakukan pengembangan produk yang dihasilkan dan memberikan jaminan atas kepuasan konsumen serta menjaga kualitas produknya. Kegiatan tersebut harus dilakukan oleh semua perusahaan agar dapat mencapai tujuannya, seperti memenuhi keinginan konsumen dan meningkatkan volume penjualan, tidak terkecuali agroindustri Abon jamur Ailani perusahaan mengolah hasil pertanian menjadi makanan siap saji yaitu jamur tiram menjadi abon dengan pertimbangan bahwa mengingat jamur tiram memiliki banyak manfaat dan khasiat.

Atribut produk pada dasarnya merupakan keunggulan dan keunikan yang dimiliki oleh produk dan merupakan pembeda antara produk sejenis yang ditawarkan oleh perusahaan dengan perusahaan lainnya. Menurut Tjiptono (2008), atribut produk adalah unsur-unsur produk yang dipandang penting oleh konsumen yang dapat dijadikan dasar untuk mengambil keputusan pembelian. Dimana atribut produk meliputi kualitas merek, kemasan, jaminan (garansi), pelayanan dan sebagainya. Sedangkan menurut Simamora (2002), atribut produk adalah faktor yang dipertimbangkan oleh konsumen dalam mengambil keputusan pembelian suatu produk seperti merek dan kategori produk, yang melekat pada produk ataupun yang menjadi bagian dari produk tersebut, yang terdiri atas harga, merek, kualitas, kemasan, ke-lengkapan fungsi dan layanan purna jual.

Penelitian mengenai pengaruh atribut produk terhadap keputusan konsumen dalam melakukan pembelian suatu produk cukup banyak dilakukan. Adapun penelitian terdahulu yang digunakan sebagai bahan masukan dan tambahan informasi dalam melakukan penelitian mengenai pengaruh atribut produk terhadap keputusan konsumen dalam pembelian suatu produk yaitu Hermianto dan Andayani (2002), Isyanto dan Herligiani (2012), Khasanah dan Pamujo (2011), Maretta dan Tarwiyah (2013), Mustafid dan Gunawan (2008), Saidani dan Ramadhan (2013). Dari keenam artikel tersebut memlakukan penelitian tentang pengaruh atribut produk terhadap keputusan pembelian konsumen.
Kehidupan produk adalah suatu grafik yang menggambarkan riwayat suatu produk sejak diperkenalkan dipasar sampai ditarik dari pasar dan siklus kehidupan produk juga membuat pasar lebih mampu mempertahankan produk yang menguntungkan dan menghentikan produk-produk yang tidak menguntungkan. Siklus kehidupan produk (life-cycle product) erat kaitannya dengan keuntungan yang didapat oleh perusahaan. Produk abon jamur Ailani ini merupakan produk yang masih dalam siklus pertumbuhan. Melihat daur hidup produk (life-cycle product) yang dapat mengalami perubahan, sehingga Perusahaan Ailanifood tetap memperhatikan keinginan konsumen serta pengembangan atribut yang digunakan dalam produk.

Ailani menciptakan olahan jamur menjadi produk makanan sehat siap saji yaitu produk abon dengan bahan baku jamur tiram putih. Saat ini semakin banyaknya bermunculan produk sejenis atau pesaing yang menarik perhatian konsumen dengan atribut produk yang berbeda seperti produk abon daging, abon ikan, dan abon jantung pisang. Sehingga konsumen memiliki banyak pilihan produk dipasaran. Keanekaragaman merk serta atribut yang ter-tanam di dalam produk dan keunggulan masing-masing dari setiap merek yang berbeda membuat presepsi konsumen juga berbeda. Serangkaian atribut yang ditawarkan oleh perusahaan merupakan salah satu cara untuk mempengaruhi keputusan konsumen.

Terdapat beberapa permasalahan yang dialami perusahaann abon jamur Ailani akibat tingginya volume penjualan. Pada tahun 2012 perusahaan Ailanifood dapat menjual abon jamur sebanyak 19.578 unit, tahun 2013 volume penjualan sebesar 24.813 unit dan tahun 2014 sebesar 14.337 unit. Oleh karena itu, perusahaan abon jamur Ailani selalu melakukan pengembangan atribut pada produk yang dihasilkannya khususnya abon jamur, sehingga dapat meningkatkan volume penjualan dari tahun ke tahun.

Berdasarkan uraian di atas, tujuan dari penelitian ini yaitu melihat pengaruh atribut produk terhadap keputusan pembelian abon jamur Ailani di kota Malang. 


\section{Metode Penelitian}

\subsection{Metode Penentuan Lokasi Penelitian}

Penentuan lokasi penelitian dilakukan secara purposive di Perusahaan Ailanifood yang berada di jalan Andromeda No. 5 Malang, Jawa Timur. Penentuan lokasi penelitian tersebut dilakukan atas pertimbangan bahwa (1) Perusahaan produk abon jamur Ailani memiliki desain kemasan yang menarik, (2) Belum pernah dilaku-kan penelitian yang menyangkut peng-aruh atribut produk terhadap keputusan konsumen, (3) Perusahaan abon jamur Ailani yang harus menghadapi keragaman atas produk yang diinginkan oleh konsumen seperti variasi rasa abon jamur. Waktu penelitian ini dilaksanakan selama 45 hari pada bulan Januari sampai bulan Februari 2015.

\subsection{Metode Penentuan Responden}

Teknik penentuan responden pada penelitian ini yaitu nonprobability sampling, yaitu accidental sampling adalah teknik pengambilan sampel yang tidak memberi peluang yang sama bagi setiap unsur atau anggota populasi untuk dipilih menjadi sampel (Sugiyono, 2004). Metode accidental sampling ini digunakan dengan alasan banyaknya populasi konsumen yang pernah membeli dan mengkonsumsi abon jamur Ailani Malang, dan responden tidak diketahui secara pasti. Sedangkan metode accidental sampling merupakan prosedur sampling yang memilih sampel dari responden yang paling mudah dijumpai atau secara kebetulan bertemu pembeli dengan peneliti maka dapat di ambil sebagai sampel Sugiyono (2005).

Pada penelitian ini jumlah sampel tidak bisa diketahui secara pasti maka untuk menentukan jumlah sampelnya menurut Rianse dan Abdi (2008) dapat ditentukan berdasarkan waktu yang digunakan untuk penelitian. maka jumlah sampel yang ditetapkan sebanyak 75 responden. Dalam penelitian ini sampel diperoleh dari konsumen abon jamur Ailani yang melakukan pembelian abon di Kota Malang yaitu di CFD (Car Free Day) di Jalan Ijen dan Brawijaya Oleh-oleh.

\subsection{Metode Pengumpulan Data Primer dan Sekunder}

Metode yang digunakan untuk mengumpulkan data dalam penelitian ini adalah sebagai berikut: a. Wawancara

Wawancara dalam penelitian ini dilengkapi dengan kuisioner, yaitu suatu daftar pertanyaan untuk memperoleh jawaban dari responden yang meliputi data yang berkaitan dengan topik skripsi. Dalam pengisian kuisioner dilakukan langsung oleh responden. Kegiatan wawancara tersebut dilakukan kepada konsumen di perusahaan abon jamur Ailani dengan menggunakan kuisioner yang berisi pertanyaan terkait dengan penelitian yang dilakukan. Menurut Rianse dan Abdi (2008) wawancara merupakan kegiatan mencari bahan (keterangan atau pendapat) dengan melalui tanya jawab lisan dengan siapa saja yang diperlukan dalam kegiatan penelitian.

\section{b. Observasi}

Observasi adalah pengamatan secara langsung terhadap objek yang diteliti untuk mengumpulkan data primer. Jadi dapat dikatakan bahwa kegiatan observasi merupakan suatu kegiatan pengamatan yang mendalam dan terlibat secara langsung di lapang yaitu dengan konsumen yang melakukan pembelian abon jamur Ailani. Dalam penelitian ini observasi dibutuhkan untuk dapat memahami proses wawancara serta konteks yang terjadi pada hasil wawancara serta untuk mengetahui gejalagejala yang muncul dalam suatu objek penelitian.

\section{c. Pengumpulan Data Sekunder}

Data sekunder adalah data yang diperoleh secara tidak langsung dari tempat penelitian yang sudah tersedia sehingga bisa langsung dikumpulkan dengan cara mengoleksi data (dokumentasi) yang berhubungan dengan hasil penelitian yang relevan dengan penelitian (Sarwono dan Martadiredja, 2008).

Dalam penelitian ini data sekunder diperoleh dari pihak internal perusahaan mengenai laporan perusahaan Abon jamur Ailani. Data sekunder ini seperti dari berbagai bahan pustaka, baik berupa jurnal ataupun buku yang berhubungan dengan materi kajian atribut produk, keputusan pembelian. Data yang diperoleh dari teori atribut produk yaitu berkenaan dengan kualitas, kemasan, harga, merek dan label produk. Dokumentasi adalah teknik pengambilan data untuk mendukung data sekunder, yang sudah ada dan dijadikan sebagai upaya untuk mengingat kembali 
proses kegiatan penelitian yang dilakukan perusahaan abon jamur Ailani Malang. Dan salah satu alat kelengkapan data yang bertujuan untuk menunjang informasi yang sudah di dapat dilapang.

\subsection{Metode Analisis Data}

\section{a. Analisis Deskriptif}

Metode analisis deskriptif merupakan metode yang digunakan dengan mengadakan pengumpulan data dan menganalisis data yang diperoleh sehingga dapat memberikan gambaran yang jelas mengenai fakta-fakta dan sifat-sifat serta hubungan antara fenomena yang telah diteliti. Dalam penelitian ini analisis deskriptif digunakan untuk menjelaskan keadaan perusahaan atau gambaran obyek serta lokasi perusahaan, karyawan perusahaan yaitu perusahaan abon jamur Ailani.

b. Analisis Kuantitatif

Analisis kuantitatif merupakan suatu bentuk analisis yang penyajiannya dalam angka-angka yang dapat diukur dan dihitung menggunakan alat analisis ataupun matematika. Tingkat ukuran yang dipakai dalam variable kemasan, kualitas, harga, merek dan keputusan konsumen adalah dengan skala likert. Hasil perhitungan dari skor atau nilai kemudian digunakan dalam analisis statistik yang dilakukan dengan menggunkan bantuan komputer, yaitu menggunkan program SPSS for Windows 20 untuk membuktikan hubungan dan pengaruh antar variable bebas seperti kemasan, kualitas, harga dan merek, sedangkan variabel terikat adalah keputusan konsumen dalam pembelian abon jamur Ailani. Uji tersebut dengan menggunakan Cochran Q test, Validitas dan Reliabilitas, Asmumsi Klasik, Regresi Berganda, Uji Koefisien Determinasi $\left(\mathrm{R}^{2}\right)$, Uji t dan Uji F.

\section{Hasil dan Pembahasan}

\subsection{Analisis Penentuan Atribut Produk}

Tabel 1. Hasil uji Cochran Q Test statistics

\begin{tabular}{lc}
\hline $\mathrm{N}$ & 40 \\
\hline Cochran's Q & $2,692^{\mathrm{a}}$ \\
\hline Df & 3 \\
\hline Asymp. Sig. &, 442 \\
\hline
\end{tabular}

a. 1 is treated as a success
Sebagai pengujian yang pertama agar penelitian ini lebih efektif dilakukan pre-test, dengan menggunakan cochran's Q. Tujuan dilakukan uji Cochran's Q untuk mengetahui variabel-variabel yang pertimbangkan dalam melakukan keputusan pembelian Abon jamur Ailani, dapat dilihat pada Tabel 1.

Setelah melakukan uji Cochran's Q terhadap atribut-atribut yang melekat maka didapat empat atribut sebagai hasil akhir sebelum dilakukan pengujian terdapat enam variabel yaitu kemasan, kualitas, harga, merek, label dan tekstur yaitu nilai Cochran's Q yaitu sebesar 111,373 atau lebih besar dari nilai Q tabel yaitu 7,815 yang artinya atribut-atribut produk tersebut belum sah untuk dijadikan variabel. Hasil tersebut diperoleh setelah membandingkan nilai Cochran's Q dengan nilai Q tabel. Nilai Cochran's Q tersebut dapat dilihat pada Tabel 1. Hasil terakhir dapat dibandingkan dengan pendapat Simamora (2004) yaitu Terima $\mathrm{H}_{0}$ dan Tolak $\mathrm{H}_{1}$, bila nilai $\mathrm{Q}$ hitung lebih kecil dari $\mathrm{Q}$ tabel. Terima $\mathrm{H}_{0}$ berarti proporsi jawaban "YA" pada semua atribut yang diuji adalah sama. Dengan demikian semua responden dianggap sepakat atau sah sebagai atribut produk Abon jamur Ailani yaitu Kemasan, Kualitas, Harga dan Merk.

\subsection{Uji Validitas}

Tabel 2. Uji Validitas

\begin{tabular}{lcc}
\hline Variabel & Item & $\begin{array}{c}\text { Corrected Item } \\
\text { Total Correlation }\end{array}$ \\
\cline { 3 - 3 } & & r hitung \\
\hline Kemasan (X1) & X1.1 & 0,641 \\
& X1.2 & 0,841 \\
& X1.3 & 0,815 \\
\hline Kualitas (X2) & X2.1 & 0,708 \\
& X2.2 & 0,820 \\
& X2.3 & 0,811 \\
\hline Harga (X3) & X3.1 & 0,671 \\
& X3.2 & 0,773 \\
& X3.3 & 0,792 \\
\hline Merek (X4) & X4.1 & 0,704 \\
& X4.2 & 0,793 \\
& X4.3 & 0,845 \\
\hline Keputusan & Y1 & 0,918 \\
Pembelian (Y) & Y2 & 0,790 \\
& Y3 & 0,891 \\
\hline
\end{tabular}

Pengujian validitas dalam penelitian ini dilakukan untuk melihat valid dan tidaknya masing-masing instrument (pertanyaan) dalam 
variabel atribut produk yang meliputi kemasan, kualitas, merek dan harga dan keputusan pembelian. Pada pengujian validitas ini diperoleh nilai $r$ tabel sebesar 0,227 dengan $\mathrm{df}=\mathrm{n}-2$ taraf signifikan (5\%). Instrumen dikatakan valid jika memenuhi syarat yaitu $r_{\text {hitung }}$ lebih besar dari pada $r_{\text {tabel }}$ dengan $\mathrm{N}=75$ orang.

Berdasarkan Tabel 2. uji validitas dapat dijelaskan bahwa semua item pertanyaan untuk variabel kemasan, kualitas, harga dan keputusan pembelian masing-masing memiliki nilai Corrected Item Total Correlation atau $r_{\text {hitung }}$ lebih besar dari pada $r_{\text {table }}$ yaitu sebesar 0,227 . Sehingga dari hasil uji validitas tersebut dapat disimpulkan bahwa semua item pertanyaan setiap variabel adalah valid, sehingga dapat dilakukan uji selanjutnya yaitu uji reliabilitas.

\subsection{Uji Reliabilitas}

Uji reliabilitas pada penelitian ini digunakan untuk mengukur suatu kestabilan dan konsistensi responden dalam menjawab hal yang berkaitan dengan konstruk-konstruk pertanya-an yang merupakan dimensi suatu variabel seperti kemasan, kualitas, harga, merek dan keputusan pembelian dalam bentuk kuisioner. Uji realibilitas dalam peneliti-an ini dilakukan secara parsial atau masing-masing variabel. Hasil uji dikatakan reliabel apabila memberi score yang konsisten pada setiap pengukuran. Uji reliabilitas meng-gunakan metode Cronbach's Alpha dengan ketentuan bahwa nilai koefisien alpha $(\alpha) \geq 0,6$ maka dapat disimpulkan bahwa instrumen yang memenuhi syarat tersebut adalah reliabel.

Berdasarkan Tabel 3. hasil uji reliabilitas dapat dijelaskan bahwa variabelvariabel dalam penelitian ini dapat dinyatakan reliabel karena tingkat konsistensi variabel seperti kemasan, kualitas, harga dan merek serta keputusan pembelian setelah dilakukan uji reliabilitas diperoleh hasil yang relatif sama atau tidak mengalami perubahan saat dilakukan pengujian dulang, sehingga hasil pengukuran tersebut dapat dipercaya yang reliabel. Setelah melakukan uji validitas dan reliabilitas, selanjutnya uji asumsi klasik untuk melihat apakah memenuhi syarat asumsi klasik, sebelum uji regresi berganda.

Tabel 3. Uji Realiabilitas

\begin{tabular}{lcc}
\hline \multicolumn{1}{c}{ Variabel } & Alpha & Keterangan \\
\hline Kemasan (X1) & 0,658 & Reliabel \\
Kualitas (X2) & 0,679 & Reliabel \\
Harga (X3) & 0,602 & Reliabel \\
Merek (X4) & 0,677 & Reliabel \\
Keputusan & 0,833 & Reliabel \\
Pembelian (Y) & & \\
\hline
\end{tabular}

\subsection{Hasil Analisis Regresi Berganda}

Analisis regresi berganda digunakan untuk melihat pengaruh variabel bebas seperti Kemasan (X1), Kualitas (X2), Harga (X3) dan Merek (X4) terhadap variabel terikat yaitu Keputusan Pembelian (Y). Hasil yang diperoleh dari uji analisis regresi terdapat pada Tabel 4.:

Tabel 4. Uji Regresi Berganda

\begin{tabular}{|c|c|c|c|c|c|c|}
\hline \multirow{2}{*}{ Model } & \multicolumn{2}{|c|}{$\begin{array}{l}\text { Unstandardized } \\
\text { coefficients }\end{array}$} & \multirow{2}{*}{$\begin{array}{c}\text { Standardized } \\
\text { Cofficients } \\
\text { Beta }\end{array}$} & \multirow{2}{*}{$\mathbf{t}$} & \multirow{2}{*}{ Sig } & \multirow{2}{*}{ Keterangan } \\
\hline & B & $\begin{array}{c}\text { Std. } \\
\text { Error }\end{array}$ & & & & \\
\hline 1 (Constant) & $-1,701$ & 1,105 & & $-1,540$ & 0,128 & \\
\hline $\operatorname{Kemasan}(\mathrm{X} 1)$ & 0,194 & 0,085 & 0,180 & 2,279 & 0,026 & Signifikan \\
\hline Kualitas (X2) & 0,280 & 0,104 & 0,241 & 2,691 & 0,009 & Signifikan \\
\hline Harga (X3) & 0,522 & 0,121 & 0,451 & 4,320 & 0,000 & Signifikan \\
\hline Merek (X4) & 0,125 & 0,110 & 0,124 & 1,129 & 0,263 & Tidak Signifikan \\
\hline \multicolumn{7}{|c|}{ Variabel Dependent : Keputusan Pembelian } \\
\hline & $R^{2}$ & \multicolumn{2}{|c|}{$=0,650$} & \\
\hline & & Adjusted R Square $=0,630$ & F hitung & \multicolumn{2}{|c|}{$=32,459$} & \\
\hline Sig F & \multicolumn{2}{|c|}{$=0,000$} & F tabel & \multicolumn{2}{|c|}{$=2,730$} & \\
\hline
\end{tabular}

Berdasarkan Tabel 4. variabel terikat pada regresi ini adalah Keputusan Pembelian $(Y)$, sedangkan variabel bebasnya adalah Kemasan (X1), Kualitas (X2), Harga (X3) dan
Merek (X4). Model regresi yang digunakan adalah Unstandardized regression karena data yang digunakan dalam penelitian ini merupakan pengukuran dengan menggunakan 
skala likert untuk mengukur sikap, pendapat dan presepsi seseorang maupun kelompok. Dalam Unstandarized regression ukuran variabel atau ukuran jawabannya telah disamakan. Adapun persamaan yang diperoleh dari tabel tersebut sebagai berikut:

$$
\begin{aligned}
\mathrm{Y}= & -1,701+0,194 \mathrm{X}_{1}+0,280 \mathrm{X}_{2}+0,522 \mathrm{X}_{3}+ \\
& 0,125 \mathrm{X}_{4}+\mathrm{e} \ldots \ldots \ldots \ldots \ldots \ldots \ldots \ldots \ldots \ldots \ldots \ldots \ldots \ldots \ldots \ldots \ldots \ldots
\end{aligned}
$$

Dari persamaan diatas dapat dijelaskan sebagai berikut:

Pada hasil uji regresi berganda dapat dilihat nilai koefisien regresi Atribut Kemasan (X1) yaitu sebesar 0,194 dan nilai signifikansinya sebesar 0,026 lebih kecil dari tingkat kepercayaan 0,05 artinya variabel Kemasan (X1) mempunyai pengaruh positif terhadap keputusan pembelian. Dan pada nilai koefisien regresi sebesar 0,194 artinya jika variabel independen lain nilainya tetap dan variabel Kemasan (X1) mengalami kenaikan 1 satuan poin, maka keputusan pembelian (Y) mengalami peningkatan sebesar 0,194.

Pada nilai koefisien regresi Atribut Kualitas (X2) sebesar 0,281 dengan nilai signifikansi sebesar 0,009 atau lebih kecil dari tingkat kepercayaan $(\alpha=0,05)$, artinya variabel Kualitas (X2) mempunyai pengaruh positif terhadap keputusan pembelian. Jika variabel independen yang lain tetap dan Kualitas mengalami kenaikan 1 satuan poin, maka keputusan pembelian (Y) mengalami kenaikan nilai sebesar 0,281.

Dari hasil uji regresi didapatkan nilai koefisien regresi Atribut Harga (X3) 0,522 dengan nilai signifikansi sebesar 0,000 atau nilai tersebut lebih kecil dari nilai $(\alpha=0,05)$, artinya variabel Harga (X3) memiliki pengaruh positif terhadap keputusan pembelian. Jika variabel independen lain nilainya tetap dan Harga (X3) mengalami kenaikan 1 satuan poin, maka nilai keputusan pembelian (Y) mengalami kenaikan sebesar 0,522. Pada nilai koefisien regresi Merek (X4) yaitu sebesar 0,125 dengan nilai signifikansi sebesar 0,263 atau lebih besar dari tingkat kepercayaan sebesar $(\alpha=0,05)$, artinya variabel merek memiliki pengaruh yang tidak nyata terhadap kepetusan pembelian. Tetapi jika variabel lain nilainya tetap dan Merek mengalami kenaikan 1 satuan poin, maka nilai keputusan pembelian akan naik sebesar 0,263.

\subsection{Uji Koefisien Determinasi $\left(\mathbf{R}^{2}\right)$}

Koefisien determinasi digunakan untuk mengetahui berapa persen pengaruh variabel bebas dalam mempengaruhi variabel terikat. Pada uji regresi sederhana dan regresi $R^{2}$ digunakan sebagai koefisien determinasi. Sedangkan untuk uji regresi berganda (lebih dari dua variabel bebas) digunakan nilai Adjusted $R^{2}$ sebagai koefisien determinasi. Berdasarkan koefisien determinasi dari hasil pengujian dapat dilihat pada tabel Model Summary, Tabel 5. sebagai berikut :

Tabel 5. Hasil Pengujian Koefisien Determinasi (Model Summary).

\begin{tabular}{cccccc}
\hline $\begin{array}{c}\text { Mo } \\
\text {-del }\end{array}$ & $\mathbf{R}$ & $\begin{array}{c}\text { R } \\
\text { Square }\end{array}$ & $\begin{array}{c}\text { Adjusted } \\
\text { R Square }\end{array}$ & $\begin{array}{c}\text { Std. Error } \\
\text { of the } \\
\text { Estimate }\end{array}$ & $\begin{array}{c}\text { Durbin- } \\
\text { Watson }\end{array}$ \\
\hline 1 & $0,806^{\mathrm{a}}$ & 0,650 & 0,630 & 1,20620 & 2,023 \\
\hline
\end{tabular}

a. Predictors: (Constant), Merek (X4), Kemasan (X1), Kualitas (X2), Harga (X3)

b. Dependen Variable: Keputusan Konsumen (Y)

Berdasarkan Tabel 5. diperoleh nilai Adjusted R Square yaitu sebesar 0,630. Hal tersebut menunjukkan bahwa $63 \%$ dapat dijelaskan oleh keempat oleh variabel bebas yaitu kemasan (X1), kualitas (X2), harga (X3) dan merek (X4). Sedangkan sisanya (100\% $63 \%=37 \%$ ) variasi keputusan pembelian dijelaskan oleh faktor-faktor lain yang tidak dijelaskan dalam model. Diduga faktor-faktor tersebut anatara lain: faktor promosi dan faktor interen konsumen seperti daya beli dan tingkat kebutuhan.

Pada tabel diatas diketahui nilai koefisien $\mathrm{R}$ yang menunjukkan seberapa erat hubungan antara variabel dependen yaitu keputusan konsumen dalam pembelian dengan variabel-variabel independen seperti kemasan, kualitas, harga dan merek didapatkan bahwa terjadi korelasi yang kuat $(0,806)$. Nilai $80,6 \%$ menunjukkan bahwa korelasi yang terjadi antara variabel $\mathrm{X}$ dan variabel $\mathrm{Y}$ adalah kuat. Tanda koefisien adalah positif menandakan bahwa hubungan yang terjadi pada penelitian ini adalah memiliki hubungan yang searah atau jika variabel-variabel independen seperti kemasan, kualitas, harga dan merek naik, maka nilai variabel dependen yaitu keputusan konsumen dalam pembelian juga naik. 


\subsection{Uji F (Simultan)}

Uji statistik $F$ pada dasarnya menunjukkan apakah semua variabel independent seperti kemasan (X1), kualitas (X2), harga (X3) dan merek (X4) yang dimasukkan dalam model mempunyai pengaruh secara bersama-sama atau serempak terhadap variabel dependen yaitu keputusan pembelian (Y). Uji F pada tingkat kepercayaan 95\% atau dengan nilai $\alpha=0,05$ serta menggunakan derajat kebebasan df (degree of freedom). Hasil uji satistik $\mathrm{F}$ tersebut yaitu dengan melihat uji ANOVA, sehingga dapat dilihat pada Tabel 6 .

Tabel 6. Hasil Analisis Uji F ( Pada Uji ANOVA)

\begin{tabular}{ccccccc}
\hline & Model & Sum of Squares & df & Mean Square & F & Sig. \\
\hline \multirow{4}{*}{1} & Regression & 188,902 & 4 & 47,226 & 32,459 & 0,000 \\
\cline { 2 - 7 } & Residual & 101,845 & 70 & 1,455 & & \\
& Total & 290,747 & 74 & & & \\
\hline
\end{tabular}

a. Dependen Variabel: Keputusan Konsumen (Y)

b. Predictors: Kemasan (X1), Kualitas (X2), Harga (X3) dan Merek (X4)

Dari Tabel 6. didapatkan hasil F hitung sebesar 32,459 dengan tingkat signifikan 0,000 serta df penyebut 4 dan df pembilang 70 . Untuk menguji hipotesis pertama yang menyatakan diduga variabel atribut produk yang terdiri dari variabel kemasan (X1), kualitas (X2), harga (X3) dan merek (X4) berpengaruh signifikan terhadap keputusan pembelian produk Abon jamur Ailani di Kota Malang maka digunakan uji F. Hasil uji $F$ dilakukan dengan membandingkan $\mathrm{F}$ hitung dengan $\mathrm{F}$ tabel pada tingkat kepercayaan $\alpha=$ 0,05. Berdasarkan Tabel 6. dapat disimpulkan bahwa nilai $F$ hitung sebesar 32,459 lebih besar dari $F$ tabel yaitu sebesar 2.50 , yang berarti pada tingkat kepercayaan $\alpha=0,05$ variabel yang meliputi kemasan, kualitas, harga dan merek secara simultan atau bersama-sama mempunyai pengaruh

Tabel 7. Hasil Analisis Uji t signifikan terhadap keputusan pembelian produk Abon jamur Ailani di Kota Malang.

\subsection{Uji t (Parsial)}

Uji statistik $t$ pada dasarnya menunjukkan seberapa jauh pengaruh satu variabel independen secara individual dalam menerangkan variasi variabel dependen. Pada uji parsial dapat dilihat nilai $t$ dan nilai signifikansi kemudian dibandingan dengan nilai $\mathrm{t}$ tabel pada tingkat kepercayaan $(\alpha=$ $0,05)$. Untuk melihat nilai t tabel yaitu dengan melihat sampel (N) sebanyak 75 dengan probabilitas sebesar 0,05 yaitu didapatkan hasil t tabel sebesar 1,992 dapat dilihat pada lampiran 10 Tabel distibusi t. Dari hasil analisis regresi linier berganda yang telah dilakukan melalui program SPSS 20 didapatkan hasil signifikan uji parsial sebagai berikut:

\begin{tabular}{|c|c|c|c|c|c|}
\hline \multicolumn{6}{|c|}{ Coefficients $^{\mathrm{a}}$} \\
\hline \multirow[t]{2}{*}{ Model } & \multicolumn{2}{|c|}{$\begin{array}{l}\text { Unstandardized } \\
\text { Coefficients }\end{array}$} & \multirow{2}{*}{$\begin{array}{c}\begin{array}{c}\text { Standardized } \\
\text { Cofficients }\end{array} \\
\text { Beta } \\
\end{array}$} & \multirow[t]{2}{*}{$\mathbf{t}$} & \multirow[t]{2}{*}{ Sig } \\
\hline & B & Std. Error & & & \\
\hline 1 (Constant) & $-1,701$ & 1,105 & & $-1,540$ & 0,128 \\
\hline Kemasan (X1) & 0,194 & 0,085 & 0,180 & 2,279 & 0,026 \\
\hline Kualitas (X2) & 0,280 & 0,104 & 0,241 & 2,691 & 0,009 \\
\hline Harga (X3) & 0,522 & 0,121 & 0,451 & 4,320 & 0,000 \\
\hline Merek (X4) & 0,125 & 0,110 & 0,124 & 1,129 & 0,263 \\
\hline
\end{tabular}

Dari hasil uji t pada Tabel 7. terdapat satu variabel independen yaitu merek (X4) tingkat signifikan uji $\mathrm{t}$ diatas 0,05 yaitu sebesar 0,263, sedangkan variabel yang nilai signifikan dibawah 0,05 yaitu kemasan (X1), Kualitas (X2) dan Harga (X3) memiliki nilai t masing-masing sebesar 0,026, 0,09 dan 0,000. Pengujian $t$ dapat dilakukan dengan hipotesis berikut:

$\mathrm{H}_{0}=$ tidak ada pengaruh yang signifikan antara variabel bebas yaitu kemasan (X1), kualitas (X2), harga (X3) dan merek 
(X4) terhadap variabel terikat yaitu keputusan pembelian (Y).

$\mathrm{Ha}=$ ada pengaruh yang signifikan antara variabel bebas seperti kemasan (X1), kualitas (X2), harga (X3) dan merek (X4) terhadap keputusan pembelian (Y).

Uji $t$ dilakukan dengan cara membandingkan antara nilai signifikan dengan tingkat signifikan 0,05 yaitu:

1. Jika nilai probabilitas 0,05 lebih kecil atau sama dengan nilai probabilitas Sig $(0,05 \leq \mathrm{Sig})$ maka $\mathrm{H}_{0}$ diterima dan $\mathrm{Ha}$ tolak artinya tidak signifikan.

2. Jika nilai probabilitas 0,05 lebih besar atau sama dengan nilai probabilitas Sig $(0,05 \geq \mathrm{Sig})$ maka $\mathrm{H}_{0}$ ditolak dan $\mathrm{Ha}$ terima yang artinya signifikan.

Dari Tabel 7. keterangan bahwa semua variabel berpengaruh signifikan karena nilai $\mathrm{t}_{\text {hitung }}$ lebih besar dari pada $\mathrm{t}_{\text {tabel }}$ kecuali pada variabel merk. Hasil ini mengindikasikan bahwa atribut merk tidak berpengaruh signifikan terhadap keputusan pembelian abon jamur Ailani.

\section{Kesimpulan}

Hasil penelitian ini menyimpulkan bahwa keempat atribut produk yang dianalisis, (kemasan, kualitas, harga, dan merk) berpengaruh secara signifikan terhadap keputusan pembelian konsumen terhadap produk abon jamur ailani, kecuali atribut merk. Dimana atribut harga memiliki pengaruh paling besar terhadap keputusan pembelian ini.

Perusahaan abon jamur Ailani sebaiknya memperhatikan Merek pada Kemasan abon jamur terutama pada tulisan merek dicetak lebih besar, agar konsumen mudah mengingat dan menghafal merek Ailani tersebut. Presepsi konsumen terhadap merek tidak terlalu diperhatikan, dikarenakan tulisan Ailani yang cukup kecil dan lebih menonjol pada tulisan "Abon Rasa". Kemasan mengunakan aluminium foil bisa buka tutup sehingga mudah dalam penyimpanan setelah produk abon jamur dibuka. Harga abon jamur tidak terlalu tinggi dan dapat dijadikan produk subtitusi abon lain.

\section{Daftar Pustaka}

[1]. Badan Pusat Statistik. 2014. Pertumbuhan Ekonomi Indonesia. Berita Resmi Statistik No. 16/02/Th. XVII, 1 Desember 2014. Jakarta.

[2]. Badan Pusat Statistik Kota Malang. 2012. Malang Dalam Angka 2011. Berita Resmi Statistik No. 35730.1101/2012. Malang.

[3]. Hermianto, J. dan Andayani. 2002. Studi Perilaku Konsumen Dan Identifikasi Parameter Bakso Sapi Berdasarkan Preferensi Konsumen Di Wilayah Jakarta. Jurnal Teknologi dan Industri Pangan. Vol.XIII. Hal 1-10.

[4]. Isyanto, E. dan Herligiani. 2012. Pengaruh Kualitas Produk Terhadap Keputusan Pembelian Handphone Blackberry Pada Mahasiswa Ekonomi Universitas Singaperbangsa Karawang. Jawa Barat.

[5]. Khasanah, I. dan Pamujo, Novian Y. 2011. Analisis Pengaruh Atribut Produk, Bauran Promosi, dan Kualitas Pelayanan terhadap Keputusan Pembelian Produk Merchandise. Jurnal. Vol 13 No 1. Hal 155-163.

[6]. Maretta, S. dan Tarwiyah. 2013. Pengaruh produk dan kualitas pelayana terhadap kepuasan konsumen pada warung-warung kaki lima di jalan sei deli Medan. Jurnal. Vol 9 No1.

[7]. Mustafid dan Gunawan, A. 2008. Pengaruh Atribut Produk Terhadap Keputusan Pembelian Kripik Pisang "Kenali" Pada PD Wira Perkaya Di Bandar Lampung. Jurnal. Vol 4 No 2.

[8]. Rianse, U. dan Abdi. 2008. Metodologi Penelitian Sosial Ekonomi. Alfabeta. Bandung.

[9]. Saidani, B. dan Ramdhan, D.R. 2013. Pengaruh Iklan Dan Atribut Produk Terhadap Keputusan Pembelian Smartphone Samsung Seri Galaxy (Survei Pada Pelanggan ITC Roxy Mas). Universitas Negeri Jakarta. Vol. 4, No.1, 2013.

[10]. Sarwono, J. dan Martadiredja, Tutty 2008, Riset Bisnis, Andi, Yogyakarta. 
[11]. Simamora, B. 2002. Panduan Riset Perilaku Konsumen. Jakarta: Pt Garamedia Pustaka Utama.

[12]. Simamora, B. 2004. Memenagkan pasar dengan pemasaran efektif dan profitabel. Jakarta: Gramedia Pustaka Utama.

[13]. Simamora dan Henry. 2004. Manajemen Pemasaran Internasional, Jilid 1. Jakarta : Salemba Empat.

[14]. Sugiyono. 2004. Metode Penelitian Bisnis. Bandung: CV. Alfabeta.

[15]. Sugiyono. 2005. Metode Penelitian Bisnis. Bandung: CV. Alfabeta.

[16]. Tjptono, F. 2001. Strategi Pemasaran. Yogyakarta: CV. Andi Offset.

[17]. Tjiptono, F. 2008. Strategi Pemasaran. Yogyakarta: CV. Andi Offset. 